\title{
The neurological founding fathers of the National Society for Epilepsy and of the Chalfont Centre for Epilepsy
}

\author{
J W A S Sander, J Barclay, S D Shorvon
}

\begin{abstract}
The National Society for Epilepsy is the largest epilepsy charity in the United Kingdom, and administers the Chalfont Centre for Epilepsy. The Society was founded in London in 1892 and its first task was to establish an agricultural colony where people with epilepsy could live and work; and this was the origin of the Chalfont Centre. Recently, details of the early history of the Society have come to light showing that neurologists from the National Hospital, Queen Square were instrumental in its foundation. The meeting in which the society was constituted was held in the house of Thomas Buzzard, chaired by David Ferrier, and its first resolution was proposed by John Hughlings-Jackson. Other neurologists associated with its early history include William Gowers, Victor Horsley, Howard Tooth, and $W$ Aldren Turner. In this paper we review the society's history and the light it throws on the attitudes to epilepsy and neurology in London in this exciting late Victorian period.
\end{abstract}

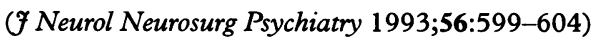

The National Society for Epilepsy (NSE) is the largest epilepsy charity in the United Kingdom, and administers the Chalfont Centre for Epilepsy, a specialised epilepsy centre on the outskirts of London. The Society was founded in the spring of 1892 in London as the National Society for the Employment of Epileptics and it is therefore also one of the oldest epilepsy societies in the world. In this paper we review the early history of the Society with special emphasis on its connection with the neurological establishment at the National Hospital, Queen Square, basing our review largely on historical and archival documents, including a series of books of minutes of the Society that were uncovered during the preparations for the Society's first centenary. This original material throws new light on the evolution of epilepsy societies in late nineteenth century Britain. We have also included as an appendix brief bibliographical sketches of the neurologists involved in the foundation of the Society.

The Society's first task was to establish an agricultural colony where people with epilepsy could live and work, hence the origin of the Chalfont Centre. The roads and houses at the Chalfont Centre for Epilepsy are named after several British philanthropists from the late 1800 s, who were generally perceived as the Society's founding fathers. Our researches of the early history of the Society show, however, that neurologists from the National Hospital, Queen Square, were instrumental in its foundation and early running; indeed, it was their impetus which interested others in setting up the Society. After several years, however, differing opinions on whether epilepsy should be viewed as a medical condition or a social problem led to the premature rupture of the relations between the neurologists and lay persons on the executive committee, and the resignation of the former. Only in the last two decades have neurologists regained influence in the running and planning of the Society's activities so that medicine and research flourished.

\section{The National Hospital}

The National Hospital for the Paralysed and Epileptics (now the National Hospital for Neurology and Neurosurgery), the first specialist neurological hospital in the world, was opened at Queen Square in 1860. True to its title, the hospital accepted patients from all over the country, the majority of them with epilepsy. Its establishment was a great step forward for the sufferers of epilepsy; in the 1870 s as many of $50 \%$ of the inpatients and an even higher proportion of the outpatients had epilepsy, and its consumption of bromides, then the only effective drug for epilepsy, was 2.5 tons annually. ${ }^{1}$ John Hughlings Jackson $^{2-4}$ was on the staff from 1862 and among his colleagues were Thomas Buzzard, $^{56}$ William Gowers, ${ }^{78}$ David Ferrier, ${ }^{910}$ and Howard Tooth. ${ }^{11}$

These were heady years for the scientific study of epilepsy. In the 1870 s Ferrier demonstrated that activation of specific areas of the cortex of animals could induce seizures in corresponding parts of the body. ${ }^{12}$ Hughlings Jackson, whose interest in epilepsy may have been triggered by the fact that his wife had what is now called "Jacksonian epilepsy, ${ }^{3}$ made original observations on many aspects of the condition. In 1873 he presented 
his definition of epileptic seizures "occasional sudden excessive, rapid and local discharges of grey matter", ${ }^{13}$ a definition still commonly used. Queen Square became the "Mecca of neurology"; epilepsy was the condition which aroused most scientific interest at the hospital, and the large number of patients with epilepsy formed the base of Ferrier's, Jackson's, and Gower's great works on the subject.

\section{The perception of epilepsy}

Clinical interest in epilepsy was accompanied by the realisation that people with epilepsy also experienced social and economic problems. Some of these problems were no different from those faced by all poor people in those times, although most arose from prevailing attitudes to epilepsy. Epilepsy was still widely regarded as a demoniac disease, one both contagious and hereditary; people with epilepsy were ostracised and their marriage frowned upon. ${ }^{14}$ Not only were they often consigned to poorhouses, asylums, houses of correction, or gaols but words like degenerate, lunatic, imbecile, idiot, feckless, and feeble-minded were used almost interchangeably with epileptic. ${ }^{15}$ The perceived and actual link between epilepsy and lunacy was particularly important; an association which had always overshadowed the life of people with epilepsy continued even towards the end of the century when the "sane epileptics" became recognised as a special group for whom, in the opinion of many, asylums and gaols were not appropriate. ${ }^{16} 17$

To a greater extent than with many other diseases, at the end of the nineteenth century, those with epilepsy were considered very definitely a class apart. The Victorian answer to problem groups (even if "sane") was to segregate them and pressure grew for institutions for epilepsy to provide care and control for life. These should be situated in the country away from the bustle of towns; by utilising the inmates' work, they might become selfsupporting. Enforced idleness and anxiety were thought to increase epileptic seizures in this feckless subclass and work was seen as a panacea. ${ }^{18}$

\section{The Society}

A number of meetings and other activities were held during the late 1880 s to discuss the needs of people with epilepsy and other handicaps. In July 1890 the Charities Organisation Society appointed a commission, which included Thomas Buzzard and David Ferrier, "to consider and report upon the public and charitable provisions made for the care and training of feeble-minded, epileptic, deformed and crippled persons"; this commission eventually lead to the foundation of the NSE. ${ }^{18}$

In April 1892, a meeting was held at the house of Thomas Buzzard in 74 Grosvenor Street in London's West End, with the specific aim of founding a society which would provide employment for patients with epilepsy in an institution to be modelled on the establishment in Bielefeld in Germany, visited by David Ferrier in the previous year. People in attendance represented three different bodies. The first were the medical staff from the National Hospital represented by Thomas Buzzard, John Hughlings Jackson, Howard Tooth, William Gowers, Joseph Ormerod, ${ }^{19}$ Walter Colman, ${ }^{20}$ and David Ferrier. The second was the Ladies' Samaritans Society of the National Hospital, Queen Square, which was formed in 1861; some members were the wives of Queen Square physicians (as then, the Ladies' Samaritans still do sterling work). This Society raised money to provide food, clothes, seaside holidays, and other comforts for poor patients from the National Hospital, Queen Square; employed lady almoners; ran a convalescent home at Finchley (now the National Hospital Rehabilitation Unit); and started a pension scheme for incurable patients. The third was the Charity Organisation Society which had been set up in 1869 by a group of philanthropists, many of whom had connections with the Jewish Board of Guardians, to prevent begging and the abuse of charity. Its members prided themselves on their scientific rather than sentimental approach to poverty and both the paid officials and voluntary members strongly upheld the work ethic and approved schemes that encouraged people to be self-supporting. The Charity Organisation Society was against state intervention in social affairs, believing that it would lead to less accountability and expenditure on unproductive schemes for feckless people. ${ }^{21}$ At this meeting the NSE was constituted, and its first resolution, proposed by Hughlings Jackson, to create " $a$ home for such epileptic persons as are capable of work but unable to obtain regular employment on account of their liability to fits" was unanimously accepted (fig 1). The second resolution proposed by David Ferrier and seconded by Howard Tooth and also approved unanimously was "that it is expedient to establish in England an industrial colony for epileptics capable of work, on the same lines, so far as circumstances should render advisable, as the colony near Bielefeld in Germany".

The Society was quickly established and by the end of May 1892 the provisional committee (later the executive committee), which included all Queen Square's physicians (fig 2) present at the inaugural meeting, also coopted into the Society a number of influential medical people. These included Victor Horsley, ${ }^{22-24}$ William Broadbent, ${ }^{25}$ John Burdon Sanderson, ${ }^{26}$ James CrichtonBrowne, ${ }^{27}$ Joseph Lister, James Paget, Andrew Clark, ${ }^{28}$ Henry Bastian, ${ }^{29}$ and Charles Beevor. ${ }^{30}$ Some of these doctors had joined the Society with a special interest, social or professional, in the fate of people with epilepsy and others, like James Crichton-Browne a "keen eugenicist", joined because such colonies helped prevent epileptics marrying. ${ }^{27}$

Further meetings of the Society were held at the house of David Ferrier or at the National Hospital, Queen Square until a 
Figure 1 Page one of the first book of minutes of the society, dated 11 April, 1892, in which the establishment of the Chalfont Centre was proposed by Drs Hughlings Fackson and David Ferrier.

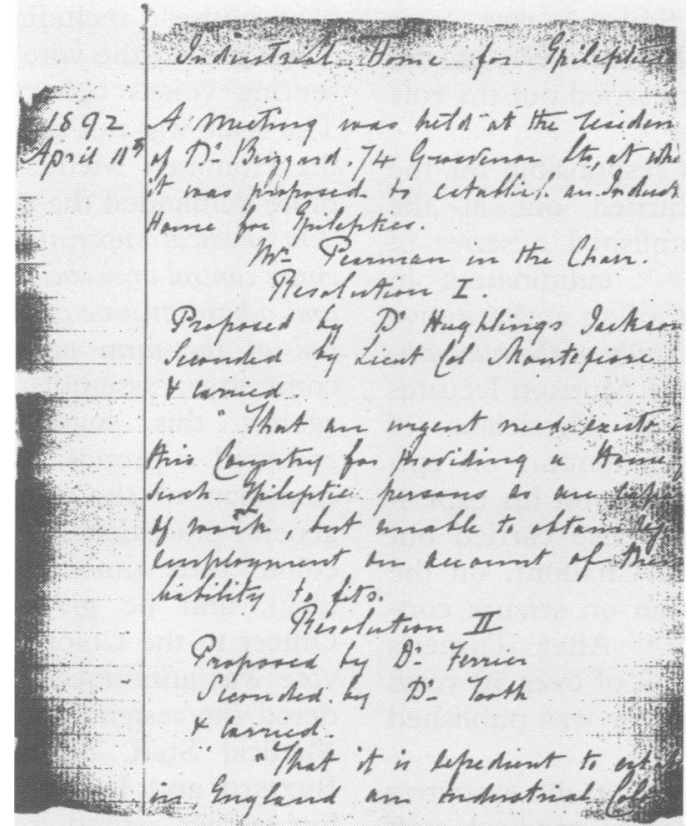

room was specially hired for this purpose, at the Medico-Chirurgical Society (latterly the Royal Society of Medicine) at Hanover Square (in London's West End). In July 1892 the society was officially named as the National Society for the Employment of Epileptics (shortened to NSE in 1907). The society was termed National (as was the Hospital in Queen Square), as it pledged to look after patients from all over the nation.

The Society's first task was to raise money to buy a farm where its "epileptic colony" could be established. In October 1892 two subcommittees were created; the first to

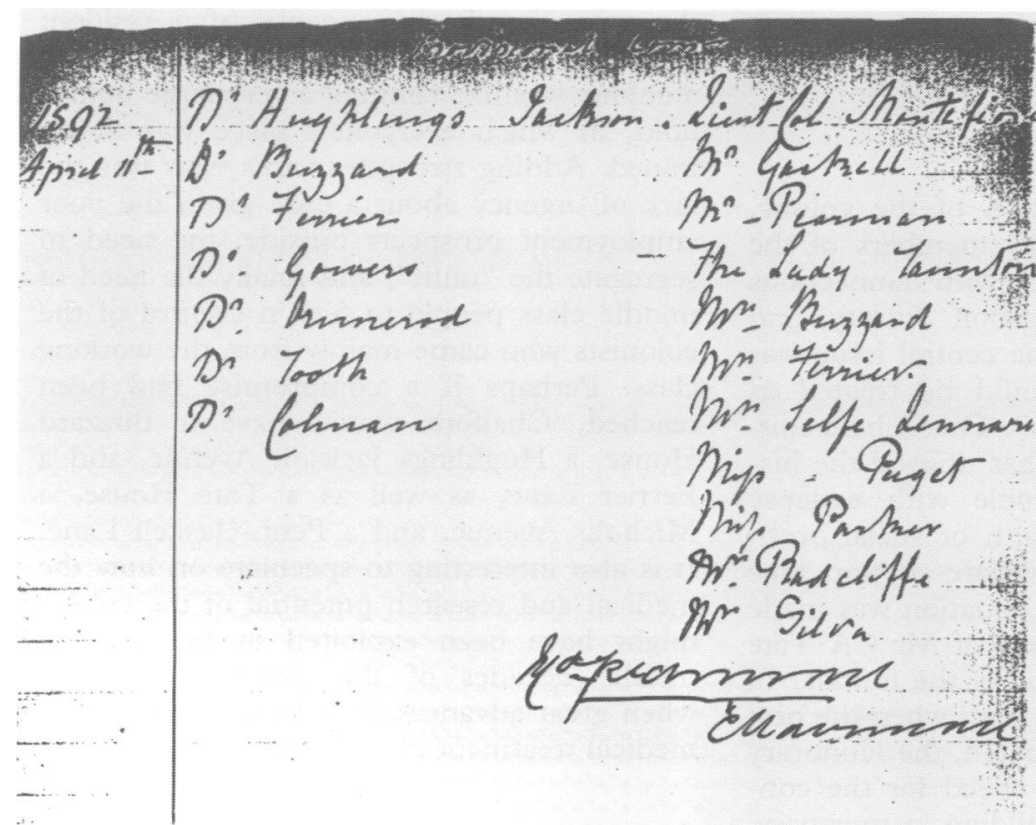

Figure 2 The minute book entry (11 April 1892) listing the first provisional committee (later the executive committee) of the Society; in the left hand comer there are the medical men (Drs Hughlings fackson, Buzzard, Ferrier, Gowers, Ormerod, Tooth, and Colman), in the right the lay members (Lieut Col Montefiore, Mr Gaskell, Mr Pearman, the Lady Taunton, Mrs Buzzard, Mrs Ferrier, Mrs Self Lennard, Mrs Paget, Miss Parker, Mrs Radcliffe, and Mrs Silva). launch an appeal to raise money and the second to find a suitable farm. A suitable farm was deemed to "be within an hour and a half of London, which was in a healthy situation, had a commodious farmhouse, 100 acres of available land, mixed soil and a good water supply".

The appeal subcommittee organised a series of events. The highlight of these, a meeting in January 1893 at the Mansion House, the official residence of the Lord Mayor of London, was well attended, and was reported in the medical and lay press. ${ }^{31-35}$ David Ferrier, one of the speakers, stated that provision would be made for all classes of the community, not only the poor; the Society did not expect to be self-supporting, but expenses would be defrayed by payment from the patients, either from their own resources or as a product of their labour. Thomas Buzzard, another speaker, stressed that they were not planning a hospital for epilepsy-the National Hospital successfully carried out that role, but rather were making provisions for a particular type of patient. $\mathrm{He}$ complained about the outrageous incarceration of epileptics in institutions for the incurable, and emphasised that patients referred for admission to the colony would require a mental and physical examination, as the colony would not provide for the insane.

Monies were raised from various sources, including families and individuals well known for their charitable works- $\mathrm{Mr}$ PassmoreEdwards, the Rothchilds, the Burdon Sandersons, and the Montefiores. The farm subcommittee had visited several farms around London and eventually in November 1893 chose and bought Skippings Farm, on Chalfont Common, 21 miles northwest from London. A year later, the colony was officially opened amid the habitual Buckinghamshire downpour of rain and howling wind and in the presence of a number of guests. The opening address was delivered by Thomas Buzzard.

A committee of the Honoary Medical Staff to the Society, which included many of the senior staff at Queen Square, was set up in June of 1893. Their brief was to look into all medical issues that might arise at the colony. The arrangements for the medical cover were finalised in a meeting at the house of Thomas Buzzard in October 1893. It was established that emergencies would be covered by the local general practitioner, Dr Charles Brooks, and that a neurologist would pay a monthly visit to the colony. The two junior neurologists at Queen Square at the time, William Aldren Turner ${ }^{36}$ and Walter Colman (a founding member of the Society), were nominated as visiting physicians, and would take turns for the monthly visits. It was also decided that the medical staff should determine the suitability of any candidate for admission to the colony, and was empowered to discharge any "colonist" on medical or other grounds. The medical staff would also be responsible for all dietary requirements and medical treatment. These arrangements persisted until 1910, although Walter Colman (who had 
resigned from Queen Square) was later replaced by Farquhar Buzzard..$^{3738}$ In the interim W Aldren Turner carried out the role of visiting physician alone.

W Aldren Turner was responsible for the first clinical research carried out at the Chalfont Colony. He published a series of papers of his findings, ${ }^{39-45}$ culminating in 1907 with the publication of an authoritative book entitled Epilepsy-a study of the idiopathic disease. ${ }^{46}$ Turner gave the Morison lectures to the Royal College of Physicians of Edinburgh, a considerable honour, on epilepsy; these were based partly on his experience at Chalfont. ${ }^{47}$ Turner also carried out the first "clinical trial" at Chalfont, on the influence of salt deprivation on seizure control (30\% effectiveness!). ${ }^{48}$ After Turner's publications there was a lull of over 50 years before another research paper was published from the Chalfont colony. ${ }^{49}$

David Ferrier, who served on the executive committee and the honorary medical staff committee, had strong connections with the colony. Dr Ferrier and his wife were instrumental in finding and choosing the site for the colony, near their own country house. $\mathrm{He}$ visited the colony very often, and in 1897 started to build his new country home in Horn Hill, less than one mile away. This house, High Trees, which featured in the architectural press at the time of its inauguration in $1904,{ }^{50}$ was built by the labour of the "colonists" in one of their first external enterprises. The house, designed by the Ferrier's architect son, Claude, who also designed most of the Colony buildings, is currently the headquarters of the British Naturist Association. Mrs Ferrier, who also served on the executive committee, took a keen interest in the running of the colony, a relationship which soured slightly because of her practice of commandeering colony nurses to perform massages at High Trees.

\section{The schism}

Soon after the inauguration of the colony, tensions arose between lay members of the executive committee, most with connections with the Charity Organisation Society, and the medical members. The central issue was whether the patients should be treated as "sick" or as "welfare cases". This debate epitomises the question that has dogged the history of epilepsy-do people with epilepsy primarily constitute a health or social problem, should medical or welfare support take priority? In 1908 a large donation was made to the Society by the estate of Mr CA Tate (the sugar baron and a son of the founder of the Tate Gallery, London) and when the best use of this money was debated, the Honorary Medical Staff committee called for the construction of a hospital building, a mortuary, and the appointment of a resident medical superintendent in charge of all administrative as well as clinical affairs. This was strongly opposed by the lay members of the executive committee who favoured the construction of new houses, including a children's home. They carried the vote by five to two, the dissenting voices being those of the Ferriers. The issue was not resolved and in early 1910, the Honorary Medical Staff committee once more demanded the appointment of a " $a$ resident medical superintendent with complete and entire control over every department, both medical and administrative of the Colony, including control of the farm operations." The executive committee, assembled in June 1910, voted against this suggestion. Furthermore, it accepted a proposal from $\mathrm{Mr}$ Micholls, the chairman of the committee, that the local general practitioner be contracted to visit the colony three times a week (and when necessary), and be given the title of Medical Officer to the Colony. After the result of the vote was announced, W Aldren Turner tendered the resignation of the entire Honorary Medical Staff. Shortly after this, Thomas Buzzard and James Crichton Browne (who had earlier retired from the executive committee) resigned in protest from the Council, the consultative body of the Society. It is possible that Hughlings Jackson, Ferrier, and Crichton Browne saw Chalfont as potentially no less fertile ground for scientific work than the West Riding Asylum in Wakefield where all three originally met, and which for a short period in the history of neurology was a centre of original thought and ideas.

A compromise might have been found had the parties not become too polarised. The medical men were anxious to ensure good treatment of the patients; it could not be denied that having a hospital, a mortuary, and above all a resident medical superintendent in charge of all aspects of the colony life, would have been a terrific boost to medical research and influence within the Society. For the non-medical members of the Society, on the other hand, the expense of a resident physician was not justified. For them running a colony was like running a very large household, in which everyone's place was determined. Adding strength to this view was the lack of urgency about a cure given the poor employment prospects outside, the need to segregate the "unfit", and finally the need of middle class people to feel in control of the colonists who came mainly from the working class. Perhaps if a compromise had been reached, Chalfont would have a Buzzard House, a Hughlings Jackson Avenue, and a Ferrier Lane, as well as a Tate House, a Micholls Avenue, and a Penn-Gaskell Lane. It is also interesting to speculate on how the medical and research potential of the colony might have been exploited in the exciting middle decades of the twentieth century, when great advances were being made in the medical treatment of epilepsy.

\section{The Society now}

The wheel has now turned full circle. The Society plays a leading role in United Kingdom clinical epilepsy research; a very successful NHS unit is now run jointly with 
the National Hospital for Neurology and Neurosurgery, and as it enters its second century, medical and administrative relations are extremely cordial even to the extent of appointing a distinguished professor of neurology as chairman of the board of governors.

\section{Appendix}

1 John Hughlings Jackson (1835-1911), born in Yorkshire, attended the York Medical School and qualified at $\mathrm{St}$ Bartholomew's Hospital in 1856. Appointed assistant physician to the National Hospital, Queen Square in 1862 , becoming full physician in 1867; he shed light on several aspects of neurology, becoming known as the "father of English neurology". ${ }^{2-4}$ Epilepsy became his essential interest and his work in this subject is still enormously influential. Early papers were those published from the West Riding Asylum in Wakefield. A quiet and withdrawn man who married his cousin, he had no known hobbies.

2 Thomas Buzzard (1831-1919), born in London, attended and qualified at King's College School of Medicine in 1857. A man of many occupations, he was present at the siege of Sebastopol, as army doctor and war correspondent for the Daily News. After working as general practitioner and as a journalist for the Lancet for six years, he became a consultant at the National Hospital, Queen Square, in 1867. He was a keen water colour painter, with many friends among the leading artists of his day. ${ }^{56}$

3 Sir William Richard Gowers (18451915), born in London, attended Oxford and qualified at University College in 1862. He became registrar at the National Hospital, Queen Square, in 1870 , assistant physician in 1873, and physician in 1880 . He wrote extensively on many aspects of neurology, including a textbook of neurology (known as "the Bible" to generations of subsequent British neurologists), seminal works on epilepsy, ophthalmoscopy, and spinal cord. His chief hobbies were etching (he illustrated many of his books and papers and exhibited at the Royal Academy), the study of mosses, and shorthand. ${ }^{78}$

4 Sir David Ferrier (1843-1928), born in Aberdeen, qualified at Edinburgh in 1868. He went into general practice in East Anglia, but after a few years joined Middlesex Hospital as a lecturer in physiology. He became a staff physician at the National Hospital, Queen Square, in 1880. His experimental work opened a new era for the understanding of brain function and he was instrumental in localising cases for early brain surgery. $\mathrm{He}$ was present at Victor Horsley's first surgical case. He was a lover of classic literature and the sea. ${ }^{910}$

5 Howard Henry Tooth (1856-1925) born in Howe, attended Cambridge and quali- fied at St Bartholomew's Hospital in 1880. He became an assistant physician at the National Hospital, Queen Square, in 1887 and staff physician in 1907 . He was also an army doctor, having served in South Africa during the Boer War. He was a talented musician, an accomplished worker in metal and wood, and a keen cyclist. ${ }^{11}$

6 Joseph Arderne Ormerod (1848-1925), born in Norfolk, attended Oxford, qualifying at St Bartholomew's Hospital in 1871. Became an assistant physician to the National Hospital, Queen Square in 1880 , and a staff physician in 1890 . He was registrar to the Royal College of Physicians from 1908 to $1925 .^{19}$

7 Walter Stacy Colman (1864-1934), born in Norfolk, attended Edinburgh University, qualifying at University College, London in 1886. He became a resident medical officer at the National Hospital in 1888, an assistant physician in 1896 resigning in 1898 to become a lecturer at St Thomas's Hospital. In his leisure time he was a keen archaeologist and freemason. ${ }^{20}$

8 Sir Victor Horsley (1857-1916), born in London, qualified at University College in 1880 . He became surgeon at the National Hospital, Queen Square, in 1886 and was an outstanding figure in the development of neurosurgery. He carried out the first neurosurgical operation for epilepsy in 1886, on James B, a case of post-traumatic epilepsy. The patient was shown at a meeting in Brighton later in the year, at which Hughlings Jackson and Charcot were present, and both congratulated Horsley on his skill. ${ }^{22}$ At a concert at the Albert Hall a few years later, Horsley's son had a first epileptic seizure and was subsequently operated on by his father. Horsley then suddenly abandoned his work at the National Hospial and became an active political militant and organiser, an antivivisectionist, a supporter of women's suffrage, and a fanatical crusader against alcohol. ${ }^{23}{ }^{24} \mathrm{He}$ died during the First World War in Mesopotamia having volunteered for the Tigris campaign.

9 Sir James Crichton-Browne (1840-1938) qualified in Edinburgh with David Ferrier. In 1866, he was appointed superintendent of the West Riding Asylum, which Hughlings Jackson and Ferrier also attended, and a series of important papers were published in the journal, Reports of the West Riding Lunatic Asylum. In 1878, he founded Brain with David Ferrier and John Hughlings Jackson. He was a founder member of the Eugenics Education Society. ${ }^{27}$

10 Henry Charlton Bastian (1837-1915), born in Truro, qualified at University College, London, in 1863. He became assistant physician at the National Hospital, Queen Square in 1868 and a staff physician in 1887 . He was made a 
fellow of the Royal Society at the age of 31 for his work on parasitology. His major contribution to neurology was his research into speech disorders. ${ }^{29}$

11 Charles Edward Beevor (1854-1908), born in London, qualified at University College, London in, 1878. He became assistant physician at the National Hospital, Queen Square in 1880 and a staff physician in 1883 . He worked with Victor Horsley on problems of cerebral localisation but his major contribution to neurology was his research into the precise morphology and distribution of the arteries of the brain. ${ }^{30}$

12 William Aldren Turner (1864-1945) was born in Edinburgh, where he qualified in 1887. He became an assistant physician at the National Hospital in 1892 and a full physician in 1900 . He was an army doctor serving in France during the First World War. He had an extensive knowledge of British and continental spas, he was also interested in antiques, and owned a fine collection of old prints. ${ }^{36}$

13 Sir Edward Farquhar Buzzard (1871-1945), born in London, the son of Thomas Buzzard, attended Oxford and qualified at St Thomas's in 1898. He became a resident medical officer at the National Hospital, Queen Square, in 1900 and a full physician in 1905. A colonel in the army medical corps during the First World War, he became physician to the Royal Family in 1924 and regius professor of medicine at Oxford in 1928. ${ }^{3738}$

1 Holmes G. The National Hospital, Queen Square; 1860 1948. London: Livingstone, 1948

2 Brown GH. Munk's roll of the Royal College of Physicians of London. Volume IV. 1826-1925. London: RCPL, 1955: 161-3.

3 Chartered Society of Queen Square. Queen Square and the National Hospital; 1860-1960. London: Edward Arnold, 1960:74-5.

4 Reynolds EH. Hughlings Jackson-a Yorkshireman's contribution to epilepsy. Arch Neurol 1988;45:675-8.

5 Brown GH. Munk's roll of the Royal College of Physicians of London. Volume IV. 1826-1925. London: RCPL, 1955: 209.

6 Chartered Society of Queen Square. Queen Square and the National Hospital; 1860-1960. London: Edward Arnold, 1960:108.

7 Brown GH. Munk's roll of the Royal College of Physicians of London. Volume IV. 1826-1925. London: RCPL, 1955: 264.

8 Chartered Society of Queen Square. Queen Square and the National Hospital; 1860-1960. London: Edward Arnold, 1960:76-7.

9 Brown GH. Munk's roll of the Royal College of Physicians of London. Volume IV. 1826-1925. London: RCPL, 1955: London.

10 Chartered Society of Queen Square. Queen Square and the National Hospital; 1860-1960. London: Edward Arnold 1960:88-9.

11 Brown GH. Munk's roll of the Royal College of Physicians of London. Volume IV. 1826-1925. London: RCPL, 1955 331.

12 Ferrier D. Experimental researches in cerebral physiology and pathology. Rep West Riding Lunatic Asylum 1873 3:30-96.
13 Jackson JH. On the anatomical, physiological and pathological investigation of epileptics. Rep West Riding Lunatic Asylum 1873;3:315-39.

14 Temkin $O$. The falling sickness: a history of epilepsy from the Greeks to the beginning of modern neurology. Baltimore: Johns Hopkins Press, 1971.

15 Berrios GE. Epilepsy and insanity during the 19th century-a conceptual history. Arch Neurol 1984;41:

16 Russel JSR. The management and education of idiots and epileptics at the Bicetre Hospital in Paris. BMF 1891; i:1247.

17 Rhodes JM. The treatment of imbeciles and epileptics. The North Midlands District Poor Law Conferences 1898; 318-9.

18 The Special Committee on Epileptics of the Charity Organisation Society. The epileptic and crippled child and adult. London: Swan Sonnerschein, 1893.

19 Brown GH. Munk's roll of the Royal College of Physicians of London. Volume IV. 1826-1925. London: RCPL, 1955: $304-5$.

20 Brown GH. Munk's roll of the Royal College of Physicians of London. Volume IV. 1826-1925. London: RCPL, 1955:393.

21 Webb B. My apprenticeship. London: Longman \& Green, 1938:177.

22 Horsley V. Brain surgery. BMF 1886;ii:670-5.

23 Chartered Society of Queen Square. Queen Square and the National Hospital; 1860-1960. London: Edward Arnold, 1960:84-5.

24 Taylor DC. One hundred years of epilepsy surgery: Sir Victor Horsley's contribution. $f$ Neurol Neurosurg Psychiatry 1986;49:485-8.

25 Brown GH. Munk's roll of the Royal College of Physicians of London. Volume IV. 1826-1925. London: RCPL, 1955: 169-70.

26 Brown GH. Munk's roll of the Royal College of Physicians of London. Volume IV. 1826-1925. London: RCPL, 1955: 137-8.

27 Farrall LA. The origin and growth of the English Eugenic Movement. PhD Thesis, Indiana University, 1970:214.

28 Brown GH. Munk's roll of the Royal College of Physicians of London. Volume IV. 1826-1925. London: RCPL, 1955: 93-4.

29 Brown GH. Munk's roll of the Royal College of Physicians of London. Volume IV. 1826-1925. London: RCPL, 1955: 174.

30 Brown GH. Munk's roll of the Royal College of Physicians of London. Volume IV. 1826-1925. London: RCPL, 1955: 325-6.

31 Anon. The National Society for the Employment of Epileptics. Lancet 1893;i:39.

32 Anon. The National Society for the Employment of Epileptics. Lancet 1893;i:165.

33 Anon. Employment of epileptics. Lancet 1893;i:217.

34 Anon. National Society for the Employment of Epileptics. BMf 1893;i:31-2.

35 Anon. Employment of epileptics. BMF 1893;i:194

36 Brown GH. Munk's roll of the Royal College of Physicians of London. Volume IV. 1826-1925. London: RCPL, 1955: 390-1.

37 Brown GH. Munk's roll of the Royal College of Physicians of London. Volume IV. 1826-1925. London: RCPL, 1955: 473-4.

38 Chartered Society of Queen Square. Queen Square and the National Hospital; 1860-1960. London: Edward Arnold, 1960:109.

39 Turner WA. A statistical inquiry into the prognosis and curability of epilepsy based upon the results of treatcurability of epilepsy based upon the
ment. Med Chir Trans 1903;86:259-91.

40 Turner WA. A statistical inquiry into the prognosis and curability of epilepsy based upon the results of treatment. Lancet 1903;i:1650-7.

41 Turner WA. The mental condition in epilepsy in relation to prognosis. Med Chir Trans 1904;87:349-71.

42 Turner WA. The mental condition in epilepsy in relation to prognosis. Lancet 1904;i:982-6.

43 Turner WA. The nature and treatment of epilepsy. Lancet 1905;i:706-11.

44 Turner WA. The influence of stigmata of degeneration upon the prognosis of epilepsy. Lancet 1905;i:426.

45 Turner WA. The influence of stigmata of degeneration upon the prognosis of epilepsy. Med Chir Trans 1905; 88: $127-45$.

46 Turner WA. Epilepsy, a study of the idiopathic disease. London: Macmillan, 1907.

47 Turner WA. The Morrison lectures on epilepsy. Lancet 1910;ii:217-20.

48 Turner WA. Salt starvation in the treatment of epilepsy. Rev Neurol Psychiatry 1904;793-8.

49 Wright JA. Trinuride in the treatment of major epilepsy. Epilepsia 1965;6:67-71.

50 Anon. "High Trees", Hornhill, Herts. The Building News 1904;26 Aug:4 